\title{
The Genetic Basis of Migraine: How Much Do We Know?
}

\author{
Kathy Gardner
}

\begin{abstract}
Migraine with and without aura is thought to be genetically complex with aggregation in families due to a combination of environmental and genetic tendencies. Twin studies are most important in establishing the multifactorial nature of migraine with heritability approaching 50\%. Familial hemiplegic migraine (FHM) on the other hand is an autosomal dominant, highly penetrant, though rare form of migraine with strong genetic tendency. Fifty percent of families with FHM are linked to chromosome 19p13 and mutations demonstrated for some in a brain expressed calcium channel alpha 1A subunit, CACNL1A4. Other FHM loci have been identified on chromosome 1q and further genetic heterogeneity is likely. The exact role of the mutated calcium channel in the pathway leading to hemiplegic migraine is yet to be established. Changes in the electrophysiologic properties of the mutated forms of the CACNL1A4 calcium channel expressed in heterologous systems help establish the functional significance of the mutations and suggest that chromosome 19p-linked FHM, an episodic disorder, represents a CNS channelopathy. Additional candidate genes causative for migraine might include other calcium channel subunits and related proteins important for neuronal membrane stability. Delineating the cascade of biochemical events leading to hemiplegic migraine will serve as a model for understanding the pathophysiology of more common forms of migraine. The evidence suggesting that some families of migraine with and without aura might also be related to the chromosome 19p locus, chromosome Xq28 locus, or DRD2 receptor polymorphisms is reviewed.
\end{abstract}

RÉSUMÉ: Les bases génétiques de la migraine: que sait-on? On pense généralement que la migraine avec et sans aura est complexe au point de vue génétique et que l'agrégation de cas dans les familles est due à une combinaison de tendances environnementales et génétiques. Les études sur les jumeaux sont très importantes pour établir la nature multifactorielle de la migraine dont l'héritabilité est de près de 50\%. D'autre part, la migraine hémiplégique familiale (MHF), une maladie autosomale dominante dont la pénétrance est élevée, est une forme de migraine rare à forte tendance génétique. Chez cinquante pourcent des familles atteintes de MHF la maladie est liée au chromosome 19, en 19p13, et chez certaines familles, des mutations ont été démontrées dans la sous-unité 1A d'un canal calcique exprimé dans le cerveau, CACNL1A4. D'autres loci ont été identifiés sur le chromosome 1, en1q, et il existe sans doute une grande hétérogénéité génétique. Le rôle exact du canal calcique muté dans la voie qui est atteinte dans la MHF n'a pas encore été établi. Les changements dans les propriétés électrophysiologiques des formes mutées du canal calcique CACNL1A4 exprimé dans les systèmes hétérologues aident à établir la signification fonctionnelle des mutations et suggèrent que la MHF liée au chromosome 19, en 19p, un trouble épisodique, représente une canalopathie du SNC. Les gènes d'autres sous-unités de canaux calciques et de protéines associées, qui sont importants pour la stabilité de la membrane des neurones, pourraient être des gènes candidats dans l'étiologie de la migraine. La définition de la cascade d'événements biochimiques conduisant à la MHF servira de modèle pour comprendre la physiopathologie de formes plus communes de migraine. Les observations suggérant que dans certaines familles atteintes de migraine avec et sans aura la maladie pourrait également être liée aux loci sur le chromosome 19, en 19p, sur le chromosome X, en Xq28, ou aux polymorphismes du récepteur DRD2 sont revues.

Can. J. Neurol. Sci. 1999; 26: Suppl. 3-S37-S43

Clinicians have long recognized the tendency for migraine to run in families, and twin studies have given us the most power to distinguish shared environment from shared genetic susceptibility as the cause for familial aggregation. Concordance rates in monozygotic twins suggest that up to $50 \%$ of the contribution to regular migraine is genetically based and indicates a multifactorial, genetically complex etiology. ${ }^{1-3}$
However, a rare subtype of migraine with aura, familial hemiplegic migraine (FHM), has a strong genetic basis with

From the Department of Neurology, University of Pittsburgh, PA, USA.

Reprint requests to: Kathy Gardner, University of Pittsburgh, Department of Neurology, S-514 Biomedical Science Tower, 3500 Terrace Street, Pittsburgh, PA 15213 
Table 1: Population based genetic epidemiology studies, regular migraine.

\begin{tabular}{lccc}
\hline & RR, $\mathbf{1}^{\mathbf{0}}$ relatives & Number of patients & $\begin{array}{c}\text { Study group } \\
\text { Denmark }^{18}\end{array}$ \\
MA & $\begin{array}{c}\sim \text { ( }(\mathrm{MOA}) \\
\text { MOA }\end{array}$ & $\sim 1700$ & \\
& $1.4(\mathrm{MA})$ & & \\
\hline MA & $1.9(\mathrm{MOA})$ & & USA $^{17}$ \\
MOA & 1.95 & $\sim 700$ & \\
\hline
\end{tabular}

$\mathrm{RR}=$ relative risk, or the risk of disease recurrence in a group (such as first degree family members to a proband) above the population prevalence. A relative risk of 1 means that disease occurs no more frequently in relatives than it does in the general population. The greater the number above 1 for relative risk, the stronger the genetic tendency and the fewer sib pairs and families needed to establish linkage or association when evaluating candidate loci or genes for migraine.

$\mathrm{MA}=$ migraine with aura

MOA = migraine without aura

autosomal dominant inheritance and genetic heterogeneity involving at least three different loci on chromosome $19 \mathrm{p},{ }^{4}$ chromosome 1q21-23, ${ }^{5}$ and chromosome 1q31. ${ }^{6}$ Chromosome 19p-linked FHM families have been associated with mutations in a brain expressed P/Q calcium channel subunit. ${ }^{7}$ The complicated interactions of the calcium channel /alpha-1A subunit with other modulatory subunits, receptor mediated G proteins, protein kinases, ${ }^{8}$ and presynaptic proteins ${ }^{9}$ impact its overall role in secretion of neurotransmitters and gene transcription. Proteins making up these modulatory complexes potentially implicate additional candidate genes important for one hemiplegic migraine "channelopathy" pathway. Hemiplegic families linked elsewhere to two separate regions on chromosome $1 \mathrm{q}^{5,6}$ await identification of the associated genes and mutations. One large family demonstrates significant linkage to both regions on chromosome $1 \mathrm{q}^{10,11}$ and has a relatively pure phenotype of just hemiparetic attacks without other migraine types. This raises the possibility that the two loci interact and is reminiscent of the polygenic complexity we expect to find in migraine with and without aura, hereafter referred to as "regular migraine". The full significance of this finding awaits further study. Some regular migraine families appear to be associated with the chromosome 19p calcium channel locus ${ }^{12,13}$ and a new locus on Xq28 has been proposed for regular migraine with $\mathrm{X}$ dominant inheritance. ${ }^{14}$ Association studies for dopamine D-2 receptor (DRD2) polymorphisms and regular migraine are reviewed ${ }^{15,16}$ and the limitations of these genetic studies for regular migraine discussed.

\section{REgUlar MigRAINE, TWIN AND POPULATION BASED EPIDEMIOLOGIC STUDIES.}

The familial aggregation of migraine has long been recognized in our clinic populations, which are perhaps naturally biased toward patients and families with greater familial tendency. One recent population based study correlated greater migraine disability in probands with higher risk of disease in family members. ${ }^{17}$ This implies that clinic patients might have a greater familial tendency if we assume that they generally present with more severe disease. Results of population-based genetic epidemiological studies have shown mild to moderate evidence for genetic tendency in regular migraine by evaluating relative risk. Relative risk compares presence of disease in first or second degree family members of a proband with the prevalence of disease in the population. A relative risk of 1 means that disease occurs no more frequently in relatives than it does in the general population. The higher the relative risk, the stronger the likelihood of a genetic contribution for the disorder. The relative risk for migraine ranges from nonsignificant 1.42 for migraine without aura or mildly increased ${ }^{17}$ to modestly increased 3.8 for migraine with aura ${ }^{18}$ (Table 1). The validity of recent epidemiologic studies have been enhanced by the use of direct interviews, more uniform International Headache Society (I.H.S.) based criteria, and population based ascertainment. However, these studies cannot differentiate familial aggregation due to shared environment from shared genetic susceptibility. ${ }^{19}$ Twin studies are most helpful in distinguishing environmental and genetic influences and several large studies of migraine in twins predict $40-50 \%$ heritability with multifactorial, polygenic inheritance (Table 2). ${ }^{2,3,20}$

On a more practical level, regular migraine is thought to be genetically complex because we cannot reliably define patterns of inheritance. A tendency for maternal transmission in many

Table 2: Twin studies, regular migraine.

\begin{tabular}{|c|c|c|c|c|}
\hline $\begin{array}{l}\text { Migraine } \\
\text { (all types) }\end{array}$ & $\begin{array}{l}0.37(37 \%) \\
0.525(52 \%) \\
0.48(48 \%) \\
0.24(24 \%)\end{array}$ & $\begin{array}{l}0.21(21 \%) \\
0.155(15 \%) \\
0.32(32 \%) \\
0.11(11 \%)\end{array}$ & $40-50 \%$ & $\begin{array}{l}\sim 5850, \text { Australia }^{3} \\
\sim 8200, \text { Finland }^{20} \\
\sim 6500 \text { o } \\
\text { Sweden }^{2} \\
\sim 12,900^{\mathbf{Y}}\end{array}$ \\
\hline
\end{tabular}

\footnotetext{
$\mathbf{o}=$ older cohort

$\mathbf{Y}=$ younger cohort
} 
Table 3. Clinical Features of Allelic CACNL1A4 Disorders and Chromosome 1q FHM families.

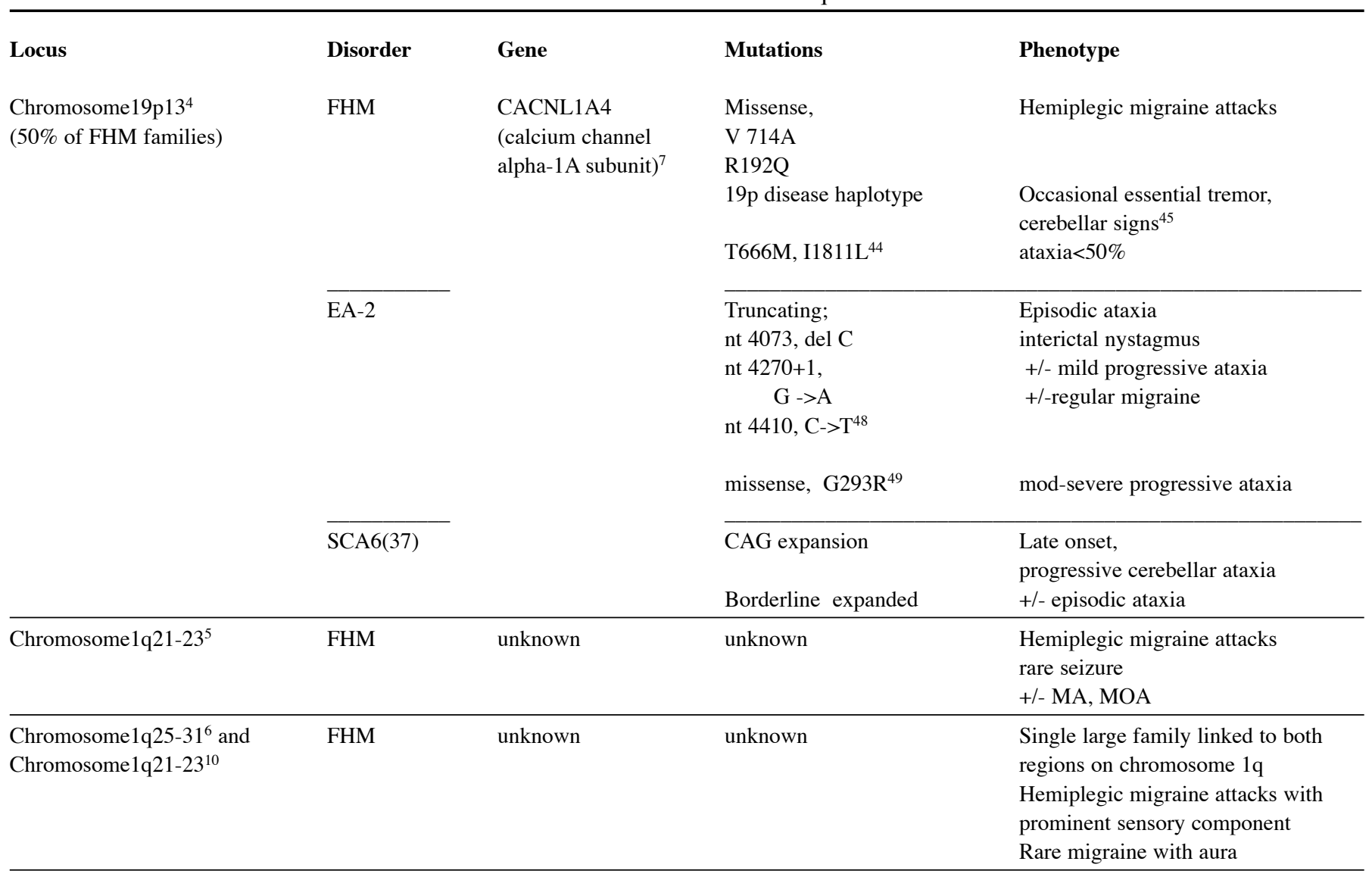

$\mathrm{FHM}=$ familial hemiplegic migraine EA-2= episodic ataxia type 2 MA = migraine with aura $\mathrm{MOA}=$ migraine without aura
SCA6=spinocerebellar ataxia type 6 Rare migraine with aura

families has long been recognized yet some families are more suggestive of dominant or even recessive inheritance. Our difficulty in establishing inheritance pattern for an individual family is due to lower and age-related disease penetrance, phenocopies (alternative causes, including nongenetic, for the disorder other than a particular gene of interest), disease in both sides of the family, and reliance on history for diagnosis of migraine. Because of this inherent ambiguity, large numbers of sibpairs and nuclear families are required for nonparametric linkage analysis and family controlled association studies of regular migraine. Statistical formulas predict the numbers needed to find linkage ${ }^{21}$ or disease association, ${ }^{22}$ using relative risk established by the population based epidemiologic studies.

\section{FAMILIAL HEMIPLEGIC MIGRAINe}

\section{Clinical features and differential diagnosis}

J.M. Clark first described hemiplegic migraine in $1910^{23}$ and more than 40 families have since been described and reviewed by Whitty. ${ }^{24,25}$ The identification of hemiplegic loci and the chromosome 19p gene described below have allowed our first phenotype-genotype correlations in those families large enough to be evaluated with linkage analysis or with mutational analysis of the calcium channel CACNL1A4 gene in the chromosome 19p families (Table 3). The clinical features of hemiplegic migraine are very similar regardless of locus involved with the exception of additional progressive ataxia in up to $50 \%$ of only chromosome $19 \mathrm{p}$ families ${ }^{26}$ and rare seizures seen with severe attacks in chromosome 1q21-23 families. ${ }^{5}$ There is variability of attack severity and side of involvement for most patients, and a spectrum of neurologic deficit ranging from coma and brain stem signs to visual scotoma, hemisensory loss, aphasia, confusion, and hemiparesis. CSF pleocytosis, meningitic signs, cerebral edema, and EEG slowing are possible additional features. ${ }^{25}$

To make the diagnosis of hemiplegic migraine, International Headache Society criteria call for two or more attacks, hemiparesis during aura, and similar attacks in at least one first degree relative in accordance with the known autosomal dominant inheritance and high penetrance seen with the disorder. ${ }^{27}$ Therefore migraineurs who have hemiparetic aura but lack similarly affected relatives are not considered hemiplegic migraineurs but instead categorized by length of aura. We do not yet know how many of these patients will represent sporadic mutations in the hemiplegic genes, reflect an uninformative family history, or are simply not related to hemiplegic genes. These migraineurs with prolonged aura are appropriately 
evaluated first for possible transient ischemic attack, often requiring extensive workup since they usually present at a young age. Note that reports of definite stroke with hemiplegic migraine are rare, atypical, ${ }^{28}$ and should raise the possibility of other disorders if family history is positive for migraine or stroke. In migraineurs with hemiparetic aura and completed stroke, especially when confirmed on imaging studies, family history should be carefully evaluated for possible maternal inheritance given that mitochondrial disorders are strongly associated with migraine that might include hemiparetic aura, especially mitochondrial encephalomyopathy, lactic acidosis, and stroke-like episodes (MELAS). ${ }^{29}$ CADASIL (cerebral autosomal dominant arteriopathy with subcortical infarcts and leukoencephalopathy) ${ }^{30}$ should also be considered in the differential, especially in the setting of progressive multi-infarct dementia, white matter disease, and positive family history that can include paternal transmission. Additionally, a role for one or several coagulation factor and apolipoprotein mutations or polymorphisms ${ }^{31-33}$ may ultimately have to be considered in any type of migraine associated with stroke, pending future clarification of complex stroke genetics.

\section{Chromosome 19p hemiplegic migraine}

The first migrainous disorder linked to chromosome 19 was CADASIL (cerebral autosomal dominant arteriopathy with subcortical infarct and leukoencephalopathy) in 1993 by a group in France. ${ }^{34}$ The same group quickly found linkage to a neighbouring region at chromosome 19p13 for hemiplegic migraine ${ }^{4}$ and for what is now called episodic ataxia type $2,{ }^{35}$ using the CADASIL locus as a candidate for these disorders because of similar episodic clinical features, including migraine. The causative gene for CADASIL associated with multi-infarct dementia, migraine, and leukoencephalopathy has since been described with missense mutations in the NOTCH 3 gene, involved in cell cycle and development. ${ }^{36}$ In 1996, the chromosome $19 \mathrm{p} 13$ gene for allelic disorders (different mutations, same gene) hemiplegic migraine and episodic ataxia type 2 was described as a P/Q voltage-gated, brain expressed, calcium channel alpha-1A pore-forming subunit. ${ }^{7}$ Four missense mutations in three different families were associated with hemiplegic migraine and truncating mutations were found responsible for episodic ataxia type 2 . Shortly thereafter, another allelic disorder associated with the channel was described as spinocerebellar ataxia type 6 (SCA6), due to minor expansions in a CAG repeat found in the 3 ' end of coding sequence of certain isoforms. ${ }^{37}$ There is some clinical or phenotypic overlap of these allelic disorders, especially with respect to ataxia, as outlined in Table 3.

The alpha-1A subunit (Figure) forms the pore through which the calcium ion passes and is made up of four domains, each containing six transmembrane segments, with segments five and six thought to form the actual pore. ${ }^{38}$ The P/Q channels are widely expressed in brain, especially cerebellum, and heavily concentrated at presynaptic nerve terminals. ${ }^{39}$ Presumably they play a significant role in synaptic transmission ${ }^{40}$ via exocytosis of dopamine and glutamate into nerve terminals. ${ }^{41}$ Channel function is controlled by a complex of additional molecules that surround the pore-forming alpha-1A subunit, including receptor mediated $\mathrm{G}$ protein ${ }^{42}$ complexed with the $\beta \gamma$ regulatory subunits. This $G$ protein- $\beta \gamma$ complex binds the domain I-II cytosolic linker of the alpha-1A subunit and together they inhibit the channel. ${ }^{8}$ Alternatively the receptor mediated $G$ protein- $\beta \gamma$ complex may be upregulated by protein kinase $\mathrm{C}$, though these effects occur most prominently in a related $\mathrm{N}$ type calcium channel, often co-expressed with the P/Q channel at presynaptic sites. $^{8}$ The domain II-III linker binds presynaptic proteins syntaxin and SNAP-25 which participate in fusion of neurotransmitter filled vesicles with the cell membrane and exocytosis. ${ }^{9}$ In summary, we are beginning to more precisely define the modulation, protein interactions, and immediate effects of the P/Q channel. The more "remote" effects of the activated channel and the signaling cascade leading to gene transcription are yet to be determined.

The FHM mutations occur in highly conserved trans-

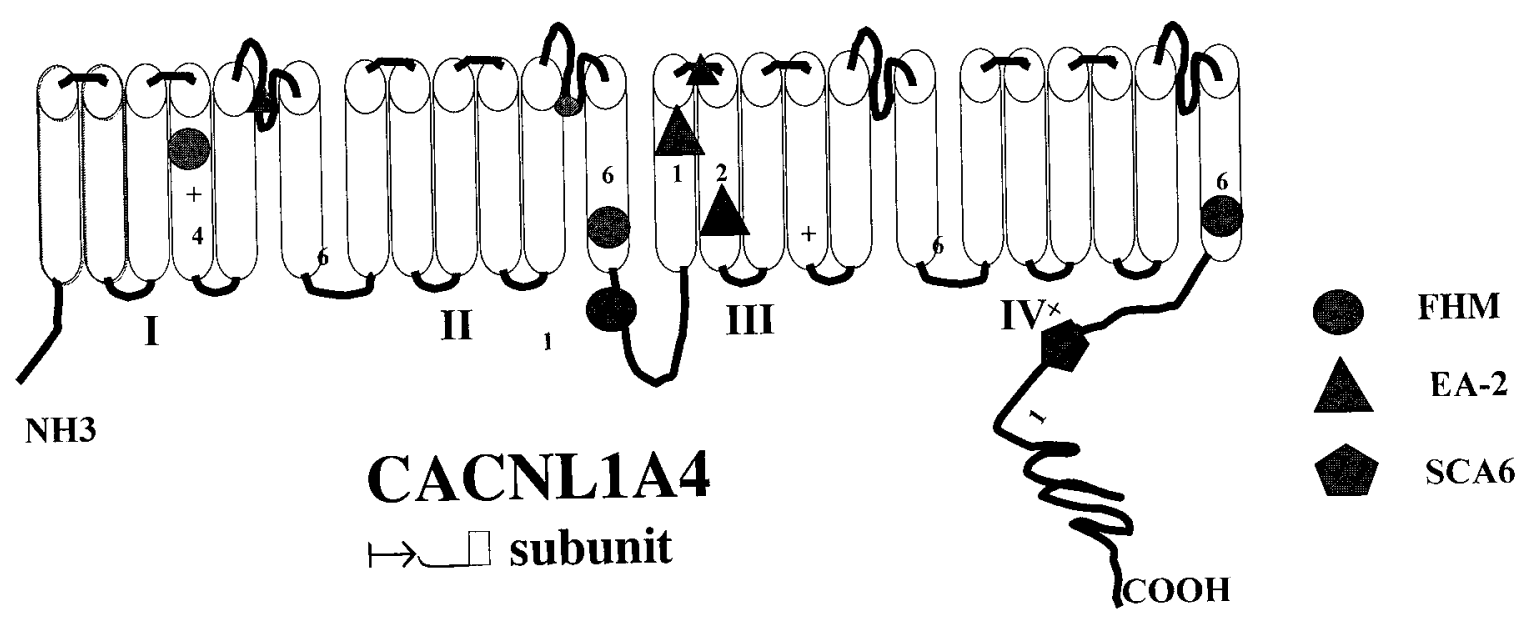

Figure: Symbols listed at top right for each of the three allelic disorders (FHM, EA-2, SCA6) associated with different mutations in the calcium channel alpha1A subunit, CACNL1A4 are used to identify the relative location for known mutations in the alphalA subunit diagram. FHM = familial hemiplegic migraine, EA-2 = episodic ataxia type 2, SCA6 = spinocerebellar ataxia type 6. 
membrane segments or loops associated with either the ion pore or the voltage-sensing S4 segment. The highly homologous rabbit alpha-1A calcium channel subunit has been mutated, expressed in Xenopus oocytes, and electrophysiologic studies performed for the four human FHM mutations. ${ }^{43}$ Compared to wild type, relatively mild changes were observed with prolonged inactivation of the channel being the most prominent finding in three of the mutations, and no abnormality found in the R192Q mutation of the S4 voltage sensor segment. During high frequency stimulation the $11811 \mathrm{~L}$ and V714A mutant channels allowed excess calcium influx, suggesting a change in function under certain "trigger" conditions. However, calcium influx decreased for the T666M mutation during high frequency stimulation. Interestingly, despite opposite effects on calcium influx, the T666M and $11811 \mathrm{~L}$ mutations have both been associated with the additional FHM phenotypic feature of progressive cerebellar neurodegeneration. ${ }^{44}$ The significance of this seeming discrepancy between specific mutation, calcium influx and neurodegeneration (ataxia component seen in some families) is unknown. Understanding the complexity of channel interactions and function will be especially challenging in vivo but necessary for clarification of $\mathrm{P} / \mathrm{Q}$ channel activity and its role in the pathophysiology of chromosome 19p hemiplegic migraine with and without ataxia.

\section{Chromosome 1q hemiplegic migraine}

There is evidence for two additional hemiplegic loci at separate regions on chromosome 1 at cytogenetic regions 1q21$23^{5}$ and at $1 \mathrm{q} 31 .{ }^{6}$ Among the 24 affected members from three French families linked to chromosome 1q21-23 hemiplegic attacks were typical, not distinguishable from the chromosome $19 \mathrm{p}$ families, except for two patients who had seizure associated with a single severe attack. Ataxia is not a clinical feature. Penetrance was lower at $76 \%$ compared with $89-90 \%$ penetrance for chromosome $19 \mathrm{p}$ families. A fair number of their chromosome 1q21-23 and chromosome 19 hemiplegic migraineurs among 13 French families had additional migraine headache types, $16 \%$ suffering migraine with aura and $34 \%$ migraine without aura, demonstrating the spectrum of migraine found in hemiplegic families. ${ }^{45}$

We found linkage in a large family with hemiplegic migraine, prominent hemisensory complaints, and rare other headache types at chromosome 1q31 with multipoint LOD score 3.3, using a candidate locus approach and searching specifically for another brain calcium channel, CACNL1A6, thought to reside in that region. ${ }^{6}$ The CACNL1A6 calcium channel was subsequently mapped more proximally, prompting evaluation of the 1q21-23 hemiplegic locus where we found a second region of linkage in the same family. ${ }^{10}$ With the addition of new affected members we narrowed both regions and found multipoint LOD scores of 5.5 in the proximal region at chromosome 1q21-23 and LOD 4.95 in the distal region at chromosome 1q31. A two-locus model favored a contribution from each locus with combined LOD score of 6.1. ${ }^{11}$ Study is underway to exclude an alternative explanation for two regions of significant linkage in a single family, such as genetic inversion not evident with high resolution karyotyping. The full significance of this finding with respect to regular or hemiplegic migraine, especially at the distal locus chromosome 1q31, awaits identification of the genetic mutation(s). The possibility that two genes contribute to a relatively pure hemiplegic phenotype in this family is reminiscent of the genetic complexity we expect to find with regular migraine and disturbs the notion that "monogenic" disorders are truly simple.

\section{REGULAR MIGRAINE LINKAGE AND ASSOCIATION STUDIES}

Complex genetic disorders require different methods of analysis for establishing genetic linkage or association than the maximum likelihood comparison of marker and disease which generates LOD scores for monogenic disorders. Nonparametric linkage methods are emphasized instead because "parameters" such as inheritance patterns and penetrance are not well defined in complex disorders. These methods rely on the principle that each person carries two alleles or copies of each gene or "marker" allele, with one allele inherited from each parent. Only one of these alleles is then passed to a child, for instance allele A from the father, and with each child subsequently born there is a fifty percent chance of passing allele A from the father. Among siblings therefore we expect $50 \%$ allele sharing for a particular gene or marker allele. Sibpair based nonparametric methods use this expected fifty percent allele sharing as a comparison among affected siblings by looking for a marker allele associated with disease more often than $50 \%$ of the time.

Alternatively, marker allele frequencies associated with disease are compared with matched case control allele frequencies or with other family member (control) allele frequencies in association studies. The association studies are potentially more efficient than sibpair studies though they are also more susceptible to false positives due to stratification of alleles among different populations and ethnic groups. The association studies also rely heavily on the likelihood that the candidate allele (polymorphism) / gene of interest is truly related to disease or very tightly linked. This often requires a difficult biochemical explanation for how a DNA polymorphism (usually thought to represent normal variation in DNA sequence) can result in disease.

\section{Linkage studies and regular migraine}

Linkage studies for regular migraine using both parametric and nonparametric analysis for evaluation of the chromosome $19 p$ hemiplegic locus have thus far shown mixed results. Some families appear not to be linked ${ }^{46}$ while other families are more or less suggestive of linkage, ${ }^{12,13}$ with much of the statistical power in each study coming from one or several families. This is what we might expect from a complex disorder presumed to be genetically heterogeneous.

A new locus for regular migraine was proposed on $\mathrm{Xq} 28$, based on suggestion of linkage in two of three large multigenerational Australian families. ${ }^{14}$ An X dominant pattern of inheritance was postulated and the general idea is enhanced by the excessive number of women migraineurs not fully explained by hormonal factors. ${ }^{47}$ However, male-to-male transmission of migraine was noted in one of the reported families with the discrepancy attributed to incoming gene from a spouse. ${ }^{14}$ The possibility of different migraine genes contributed by spouses and "nonpenetrant" or unaffected family members carrying disease genes will always make the linkage and association analysis of regular migraine more difficult, requiring larger study groups to confirm findings. 


\section{DRD2 receptor association studies}

Association studies for regular migraine have suggested that dopamine type 2 receptor (DRD2) polymorphisms may play some role in certain migraine subgroups. Polymorphisms are thought to represent normal variation in DNA sequence without obvious change, for instance, in coded proteins. However, there is growing suspicion that the additive effects of minor functional changes induced by polymorphisms in one or more genes could be important in the pathophysiology of complex genetic disorders.

Different methods and populations were used in studies looking at two different marker alleles or polymorphisms in exon 6 and intron 1. A case controlled study found an association with an exon $6, \mathrm{NcoI}$ restriction site polymorphism in migraine with aura. ${ }^{15}$ A family controlled transmission dysequilibrium test in a relatively isolated Sardinian population found an association between an intron 1, TG repeat polymorphism and a subgroup of "dopaminergic" migraineurs without aura. ${ }^{16}$

The functional significance of the DRD2 receptor and migraine is attributed to the clinical observation of vegetative "dopaminergic" symptoms that often accompany migraine attack and because DRD2 antagonist pharmacotherapy is often effective in providing relief for the acute attack. Establishing the functional significance at a biochemical level, however, will be more difficult, especially if the polymorphism itself must be implicated. It will likely be easier to interpret the findings of our association studies in regular migraine once a single migraine pathway is fully established, such as the hemiplegic chromosome $19 \mathrm{p}$ calcium channel pathway.

\section{CONCLUSION}

Rare hemiplegic migraine families have the strongest genetic basis of all migraine types and have the greatest potential for contributing to an understanding of migraine pathophysiology using molecular genetic techniques. Chromosome 19p-linked hemiplegic migraine families have been associated with mutations in a brain expressed $\mathrm{P} / \mathrm{Q}$ calcium channel subunit CACNL1A4, important in neurotransmitter release at presynaptic nerve terminals and with effects on gene transcription yet to be described. Delineation of the signaling pathways for this calcium channel will further our understanding of one genetically based migraine disorder thought to represent a CNS "channelopathy". It will require work in orthologous mammalian systems, and has potential for identifying important new candidate genes for regular migraine. Identification of new hemiplegic genes has equal potential for establishing migraine pathways and collectively we expect them to shed light on the pathophysiology of all migraine and vascular headache disorders.

Sibpair and association studies in regular migraine may ultimately broaden our understanding of regular migraine against the framework of hemiplegic migraine pathways. However, the genetic complexity and heterogeneity of regular migraine hamper, the immediate usefulness of linkage studies in the search for new genes, requiring large study groups and improved methods for identifying candidate genes. Likewise, association studies for regular migraine are limited by technical concerns regarding population stratification among case controls, identification of strong candidate genes, and our current inability to establish the functional significance of DNA polymorphisms or to find the nearby causative mutation in a genetically heterogenous test group of regular migraineurs.

\section{REFERENCES}

1. Honkasalo ML, Kapri J, Heikkila K, Sillanpaa M, Koskenvuo M. A population-based survey of headache and migraine in 22,809 adults. Headache 1993; 33:403-12.

2. Larsson B, Bille B, Pedersen NL. Genetic influence in headaches: a Swedish twin study. Headache 1995; 3:513-519.

3. Merikangas K, Tierney C, Martin N, Heath A and NR. Genetics of Migraine in the Australian Twin Registry. In: New Advances in Headache Research 4. Ed. Rose C. London: Smith-Gordon and Company Ltd, 1994: 27-28.

4. Joutel A, Bousser MG, Biousse V, Labauge P, Chabriat $\mathrm{H}$ et al. A gene for familial hemiplegic migraine maps to chromosome 19 . Nature Genetics 1993; 5:40-45.

5. Ducros A, Joutel A, Vahedi K, Cecillon M, Ferreira A, Bernard E et al. Mapping of a second locus for familial hemiplegic migraine to 1q21-23 and evidence of further genetic heterogeneity. Ann Neurol 1997; 42:885-890.

6. Gardner K, Barmada MM, Ptacek LJ, Hoffman, EP. A new locus for hemiplegic migraine maps to chromosome 1q31. Neurology 1997; 49:1231-1238.

7. Ophoff RA, Terwindt GM, Vergouwe MN et al. Familial hemiplegic migraine and episodic ataxia type- 2 are caused by mutations in the Ca2+ channel gene CACNL1A4. Cell 1996; 87:543-552.

8. Zamponi GW, Bourinet E, Nelson D, Nargeot J, Snutch TP. Crosstalk between $\mathrm{G}$ proteins and protein kinase $\mathrm{C}$ mediated by the calcium channel alpha1 subunit. Nature 1997; 385:442-426.

9. Rettig J, Sheng ZH, Kim DK et al. Isoform-specific interaction of the alpha1A subunits of brain $\mathrm{Ca} 2+$ channels with the presynaptic proteins syntaxin and SNAP-25. Proc Natl Acad Sci USA 1996; 93:7363-7368.

10. Gardner K, Badger J, Barmada MOCJ, Hoffman E. Expansion of the Chromosome 1q31 locus for hemiplegic migraine. In: Genetics of Headache Disorders. Frontiers in Headache Research. Vol. 8. Eds Olesen J, Bousser M. New York: Lippincott-Raven Publishers, NY, 1998.

11. Gardner KBJ, Barmada MM, O’Connell J, Hoffman EP. A two locus model for hemiplegic migraine on Chrlq and candidate gene screening (abstract). Am J Human Genetics 1998; 63:A30, 154.

12. May A, Ophoff RA, Terwindt GM et al. Familial hemiplegic migraine locus on 19p13 is involved in the common forms of migraine with and without aura. Human Genetics 1995; 96:604608.

13. Nyholt DR, Lea RA, Goadsby PJ, Brimage PJ, Griffiths LR. Familial typical migraine: linkage to chromosome 19p13 and evidence for genetic heterogeneity. Neurology 1998; 50:1428-32.

14. Nyholt DR, Dawkins JL, Brimage PJ, Goadsby PJ, Nicholson GA, Griffiths LR. Evidence for an X-linked genetic component in familial typical migraine. Human Molecular Genetics 1998; 7:459-463.

15. Peroutka SJ, Wilhoit T, Jones K. Clinical susceptibility to migraine with aura is modified by dopamine D2 receptor (DRD2) NcoI alleles. Neurology 1997; 49:201-6.

16. Del Zompo M, Cherchi A, Palmas MA et al. Association between dopamine receptor genes and migraine without aura in a Sardinian sample. Neurology 1998; 51:781-786.

17. Stewart WF, Staffa J, Lipton RB, Ottman R. Familial risk of migraine: a population-based study. Ann Neurol 1997; 41:166172.

18. Russell MB, Iselius L, Olesen J. Migraine without aura and migraine with aura are inherited disorders. Cephalalgia 1996; 16:305-309.

19. Merikangas KR. Genetics of migraine and other headache. Current Opinion in Neurology 1996; 9:202-205. 
20. Honkasalo ML, Kaprio J, Winter T et al. Migraine and concomitant symptoms among 8167 adult twin pairs. Headache 1995; 35:70-78.

21. Risch N. Linkage strategies for genetically complex traits. II. The power of affected relative pairs. Am J Hum Genet 1990; 46:229241 .

22. Risch N, Merikangas K. The future of genetic studies of complex human diseases. Science 1996; 273:1516-1517.

23. Clark J. On recurrent motor paralysis in migraine. Br Med J 1910; 1:1534-1538..

24. Whitty C. Familial hemiplegic migraine. J Neurol Neurosurg Psychiatry 1953; 16:172-177.

25. Whitty, C.W.M. Familial hemiplegic migraine. Handbook of Clinical Neurology. Elsevier Science Publishers, 1986. 141-153.

26. Ducros A, Joutel A, Vahedi K, Bousser M, Tournier-Lasserve E. Genotype-phenotype correlations in familial hemiplegic migraine (FHM). Neurology 1998; 50:A352.

27. Headache Classification Committee of the International Headache Society. Classification and diagnostic criteria for headache disorders, cranial neuralgias and facial pain. Cephalagia Suppl 1988; 8:19-28.

28. Hayashi R, Tachikawa H, Watanabe R et al. Familial hemiplegic migraine with irreversible brain damage. Comorbid migraine with aura, anxiety, and depression is associated with dopamine D2 receptor (DRD2) NcoI alleles. Intern Med 1998; 37:166-168.

29. Montagna P, Gallassi R, Medori R et al. MELAS syndrome: characteristic migrainous and epileptic features and maternal transmission. Neurology 1988; 38:751-754.

30. Tournier-Lasserve E, Iba-Zizen MT, Romero N, Bousser MG. Autosomal dominant syndrome with strokelike episodes and leukoencephalopathy. Stroke 1991; 22:1297-1302.

31. Auburger G. New genetic concepts and stroke prevention. Cerebrovasc Dis 1998; 8 Suppl 5:28-32.

32. Aalto-Setala K, Palomaki H, Miettinen $\mathrm{H}$ et al. Genetic risk factors and ischaemic cerebrovascular disease: role of common variation of the genes encoding apolipoproteins and angiotensinconverting enzyme. Ann Med 1998; 30:224-233.

33. Kontula K, Ylikorkala A, Miettinen $\mathrm{H}$ et al. Arg506Gln factor V mutation (factor $\mathrm{V}$ Leiden) in patients with ischaemic cerebrovascular disease and survivors of myocardial infarction. Thromb Haemost 1995; 73:558-560.

34. Tournier-Lasserve E, Joutel A, Melki J et al. Cerebral autosomal dominant arteriopathy with subcortical infarcts and leukoencephalopathy maps to chromosome 19q12. Nature Genetics 1993; 3:256-259.

35. Vahedi K, Joutel A, Van Bogaert P et al. A gene for hereditary paroxysmal cerebellar ataxia maps to chromosome 19p. Ann Neurol 1995; 37:289-293.

36. Joutel A, Corpechot C, Ducros A et al. Notch3 mutations in CADASIL, a hereditary adult-onset condition causing stroke and dementia. Nature 1996; 383:707-710.

37. Zhuchenko $\mathrm{O}$, Bailey $\mathrm{J}$, Bonnen $\mathrm{P}$ et al. Autosomal dominant cerebellar ataxia (SCA6) associated with small polyglutamine expansions in the alpha 1A-voltage-dependent calcium channel. Nature Genetics 1997; 15:62-69.

38. Stea A, Soong TW, Snutch TP. Voltage-gated calcium channels. Handbook of Receptors and Channels. CRC Press, Inc, 1995; 113-151.

39. Westenbroek RE, Sakurai T, Elliott EM et al. Immunochemical identification and subcellular distribution of the alpha $1 \mathrm{~A}$ subunits of brain calcium channels. J Neurosci 1995; 15:6403-6418.

40. Takahashi T, Momiyama A. Different types of calcium channels mediate central synaptic transmission. Nature 1993; 366:156-158.

41. Elliott EM, Malouf AT, Catterall WA. Role of calcium channel subtypes in calcium transients in hippocampal CA3 neurons. $\mathrm{J}$ Neurosci 1995; 15:6433-6444.

42. Zhang JF, Ellinor PT, Aldrich RW, Tsien RW. Multiple structural elements in voltage-dependent $\mathrm{Ca} 2+$ channels support their inhibition by G proteins. Neuron 1996; 17:991-1003.

43. Kraus RL, Sinnegger MJ, Glossmann H, Hering S, Striessnig J. Familial hemiplegic migraine mutations change alpha1A Ca2+ channel kinetics. J Biol Chem 1998; 273:5586-5590.

44. Terwindt GM, Ophoff RA, Haan J et al. Variable clinical expression of mutations in the P/Q-type calcium channel gene in familial hemiplegic migraine. Dutch Migraine Genetics Research Group. Neurology 1998; 50:1105-1110.

45. Ducros A, Joutel A, Vahedi K, Bousser M, Tournier-Lasserve E. Genotype-phenotype correlations in familial hemiplegic migraine (FHM). 8th International Headache Research Seminar; Genetics of Headache Disorders 1997; (abstract) 31.

46. Hovatta I, Kallela M, Farkkila M, Peltonen L. Familial migraine: exclusion of the susceptibility gene from the reported locus of familial hemiplegic migraine on 19p. Genomics 1994; 23:707-709.

47. Stewart WF, Shechter A, Rasmussen BK. Migraine prevalence. A review of population-based studies. Neurology 1994; 44:S17-23.

48. Yue Q, Jen JC, Thwe MM, Nelson SF, Baloh RW. De novo mutation in CACNA1A caused acetazolamide-responsive episodic ataxia. Am J Med Genet 1998; 77:298-301.

49. Yue Q, Jen JC, Nelson SF, Baloh RW. Progressive ataxia due to a missense mutation in a calcium-channel gene. Am J Hum Genet 1997; 61:1078-1087. 